\title{
Semi-volatile Compounds Variation among Brazilian Populations of Ilex paraguariensis St. Hil.
}

\author{
Rogério Luis Cansian ${ }^{1 *}$, Altemir José Mossi ${ }^{1}$, Márcio Mazutti ${ }^{1}$, José Vladimir Oliveira ${ }^{1}$, \\ Natalia Paroul $^{1}$, Cláudio Dariva ${ }^{1}$ and Sérgio Echeverrigaray ${ }^{2}$ \\ ${ }^{1}$ Laboratório de Biotecnologia; Departamento de Ciências Agrárias; URI-Campus de Erechim; Av. 7 de Setembro, \\ 1621; cansian@uricer.edu.br; 99700-000; Erechim - RS -Brasil. ${ }^{2}$ Instituto de Biotecnologia; Universidade de \\ Caxias do Sul; Rua Francisco Getulio Vargas,1130; selaguna@yahoo.com; 95001-560; Caxias do Sul - RS - Brasil
}

\begin{abstract}
The use of compressed carbon towards extracting semi-volatile compounds present in maté leaves (Ilex paraguariensis St. Hil.) is due to the growing interest in mate constituents to develop new products in the cosmetic, pharmaceutical and food industries. The objective of this work was to assess the chemical distribution of semivolatile compounds in 20 native populations of maté collected all over Brazil. The extracts of bulk samples (30 plants) of each population were obtained by the high-pressure carbon dioxide extraction technique, and analyzed by GC/MSD. The quantification of compounds (caffeine, theobromine, phytol, squalene, vitamin E, eicosane, pentatriacontane, and stigmasterol) showed significant variations within the different populations and compounds analyzed, which are not related to geographical origin or macroclimate characteristics. The results pointed out to the importance of genetic and local environmental factors on the chemical composition of this species.
\end{abstract}

Key words: Maté, chemical variability, Brazilian native populations, supercritical extraction

\section{INTRODUCTION}

Ilex paraguariensis St.Hil., popularly known as "maté tree", is a perennial South American tree of family Aquifoliaceae (Coelho et al., 2002). The natural dispersion area of $I$. paraguariensis is about 5,400,000 $\mathrm{km}^{2}$ distributed in Brazil, Paraguay and Argentina. Brazil has around $80 \%$ of the area of the occurrence of this species (Winge et al., 1995) distributed in south and middle west regions, including the highlands of the states of Rio Grande do Sul, Santa Catarina, Paraná, São Paulo, Minas Gerais and Mato Grosso do Sul. In general, the maté tree is found associated with araucaria forests (Oliveira and Rotta, 1985).
Used since ancient times, maté became an important natural product in the economic and cultural context of South Brazil, Paraguay, and Argentina, with an average annual production of more than three hundred thousand tons, being most of which locally consumed. Maté quality is associated with bitter taste, smell, and strongness of the infusion, which depends on the volatile and semi-volatile compounds present in the leaves. The beverage prepared by the infusion of green or dried maté leaves is highly appreciated for its stimulating, antirheumatic, diuretic and digestive properties, which are related to the presence of caffeine, theophylline, and theobromine (Clifford and Ramirez, 1990; Saldaña et al., 1999). Steam distillation of green and roasted maté leaves

${ }^{*}$ Author for correspondence 
allowed to identify more than 250 volatile compounds, which influence maté tea smell and flavor, including linalool, $\alpha$-terpineol, geraniol, nerolidol, and ionone-related compounds (Kawakami and Kobayashi, 1991).

In last ten years, some papers have been published focusing on the extraction of mate with carbon dioxide at high pressures. Saldaña et al. (1999, 2000) reported the identification of methylxanthines and discussed the solubility of maté alkaloids in carbon dioxide, and Esmelindro et al. (2005) studied the influence of industrial manufacturing steps on the volatile compounds of maté leaves. Esmelindro et al. (2004) investigated the influence of agronomic variables on the chemical distribution of some compounds present in the extracts of maté obtained from high-pressure carbon dioxide extraction. Thus, the use of carbon dioxide to extract semi-volatile compounds present in maté has proven to be a useful technique and a matter of great interest, especially for developing new products in the food and pharmaceutical industries.

The publications cited above concerning the extraction and identification of compounds of maté with carbon dioxide are related to local samples, i.e. a unique population was investigated in each study. In this context, the presented work aim to investigate the variability of semi-volatile compounds among twenty natural populations of Ilex paraguariensis collected in all the area of occurrence of this species in Brazil. The final objective of this work was to contribute for the preservation of the variability of the species, and for the selection of populations with desired chemical composition to be explored in breeding programs.

\section{MATERIALS AND METHODS}

\section{Plant samples}

Twenty natural populations of Ilex paraguariensis, originated from four Brazilian states: Rio Grande do Sul (Áurea, Barão de Cotegipe, Coronel Barros, Erechim, Flores da Cunha, Ilópolis, Machadinho, São Francisco de Paula, Venâncio Aires and Victor Graeff), Santa Catarina (Bocaina do Sul, Caçador, Catanduvas, Chapecó and Urubici), Paraná (Cascavel, Irati, Francisco Beltrão and São Mateus do Sul), and Mato Grosso do Sul (Ponta Porã), were sampled.
In this study it were considered as natural populations the groups of not cultivated plants with natural occurrence in a continuous original forest and separated geographically by at least 30 $\mathrm{km}$. The populations were represented by 30 adult plants (200g/plant), randomly collected to represent all the area occupied by a population and with a minimum distance of $20 \mathrm{~m}$ between plants. Samples were collected during the winter (June and July), and immediately dried at room temperature.

For each population, three groups of ten adult plants were formed, and the bulked samples were triturated and sieved, collecting 100 to 200 mesh particles. The bulked samples were stored at room temperature under nitrogen atmosphere until the extraction.

\section{Extraction procedure}

The extraction was performed in a laboratory-scale high-pressure carbon dioxide unit constructed according with Rodrigues et al. $(2003,2004)$ and Sousa et al. (2005). Basically, the apparatus consists of a $\mathrm{CO}_{2}$ reservoir, two thermostatic baths, a syringe pump (ISCO 500D), a $0.1 \mathrm{dm}^{3}$ jacketed extraction vessel, an absolute pressure transducer (Smar, LD301) equipped with a portable programmer (Smar, HT 201) with a precision of \pm 0.125 bar, a collector vessel with a glass tube, and a cold trap.

Powdered leaves samples $(25 \mathrm{~g})$ were charged into the extraction vessel. The $\mathrm{CO}_{2}$ was pumped at a constant flow rate of $2 \mathrm{~g} \mathrm{~min}^{-1}$ into the bed, which was supported by two 300 mesh wire disks at both ends of the extractor. $\mathrm{CO}_{2}$ was kept in contact with the herbaceous matrix for one hour to allow the stabilization of the system. Afterwards, the extract was collected by opening the micrometering valve. During this process, the $\mathrm{CO}_{2}$ mass flow was monitored by a pump recorder. At the end of the process the extract was weighed and transferred to an appropriate vessel. All the extractions were conducted under constant temperature and pressure of $50^{\circ} \mathrm{C}$ and $175 \mathrm{bar}$, respectively. Duplicate runs were performed for all samples.

\section{Extract analysis}

The extracts were analyzed through GC/MSD (Shimadzu QP5050A), using a capillary column DB5 (30m, 0,25mm, 25 $\mu \mathrm{m})$. Column temperature was programmed $70^{\circ} \mathrm{C} / 3 \mathrm{~min}, 4^{\circ} \mathrm{C} / \mathrm{min}$ to $260^{\circ} \mathrm{C}$, $2.5^{\circ} \mathrm{C} / \mathrm{min}$ to $300^{\circ} \mathrm{C} / 25 \mathrm{~min}$. Helium was the carrier gas and the injection port and detector 
temperatures were $290^{\circ} \mathrm{C}$ and $300^{\circ} \mathrm{C}$, respectively. The sample $\left(1 \mu \mathrm{L}\right.$ of $40000 \mathrm{mgL}^{-1}$ in $\left.\mathrm{CH}_{2} \mathrm{Cl}_{2}\right)$ components were identified by matching their mass spectra with those of Wiley library database and by comparison of retention times with standards. In all samples was added an internal standard (biphenyl 100ppm) and the content of each compound was calculated by the ratio between the peak area of the compound by the peak area of internal standard. Caffeine, theobromine, phytol, squalene, vitamin E, eicosane and stigmasterol were quantified through the injection of authentic standards (Sigma-Aldrich Co). Three replications were performed for each sample.

\section{Statistical analysis}

The main constituents of the extracts were used for multivariate analysis. Descriptive statistics, mean Euclidian distances, and hierarchical cluster analysis (Unweighted Pair Group Mean Algorithm - UPGMA algorithm) were performed with the appropriate procedures of the computer package Statistica ${ }^{\circledR} 5.5$.

\section{RESULTS AND DISCUSSION}

The extraction yield using supercritical carbon dioxide method ranged from 0.59 to $0.86 \mathrm{~g}$ of extract/100g of raw material (dry weight) depending on the population. Fig. 1 presents a typical chromatogram obtained from the GC/MSD analysis of the extracts obtained by supercritical carbon dioxide extraction in which the following constituents were identified: caffeine (34.375 min.), theobromine (34.658 min.), phytol (40.842 min.), eicosane (53.258 $\mathrm{min}$.), squalene (56.075 min.), pentatriacontane (57.500 $\mathrm{min})$, vitamin-E (62.800 $\mathrm{min}$.$) , and stigmasterol (67.083 \mathrm{min}$.). Other compounds (5 hydrocarbons, 2 aldehydes, 2 alcohols, 1 ketone and 1 aromatic) were identified by matching their spectra with those of the Wiley library, but attempt to quantified them was not pursued due to the low confidence indicated by the chemical analysis.

As expected, the compounds extracted by supercritical carbon dioxide method represented a fraction of the overall volatile and semi-volatile components of maté tree leaves. Extracts composition and methylxanthines yields obtained in the present work were comparable to those reported by Saldaña et al. (1999, 2000) and Esmelindro et al. (2004), indicating that the parameters adopted for the extraction were efficient.

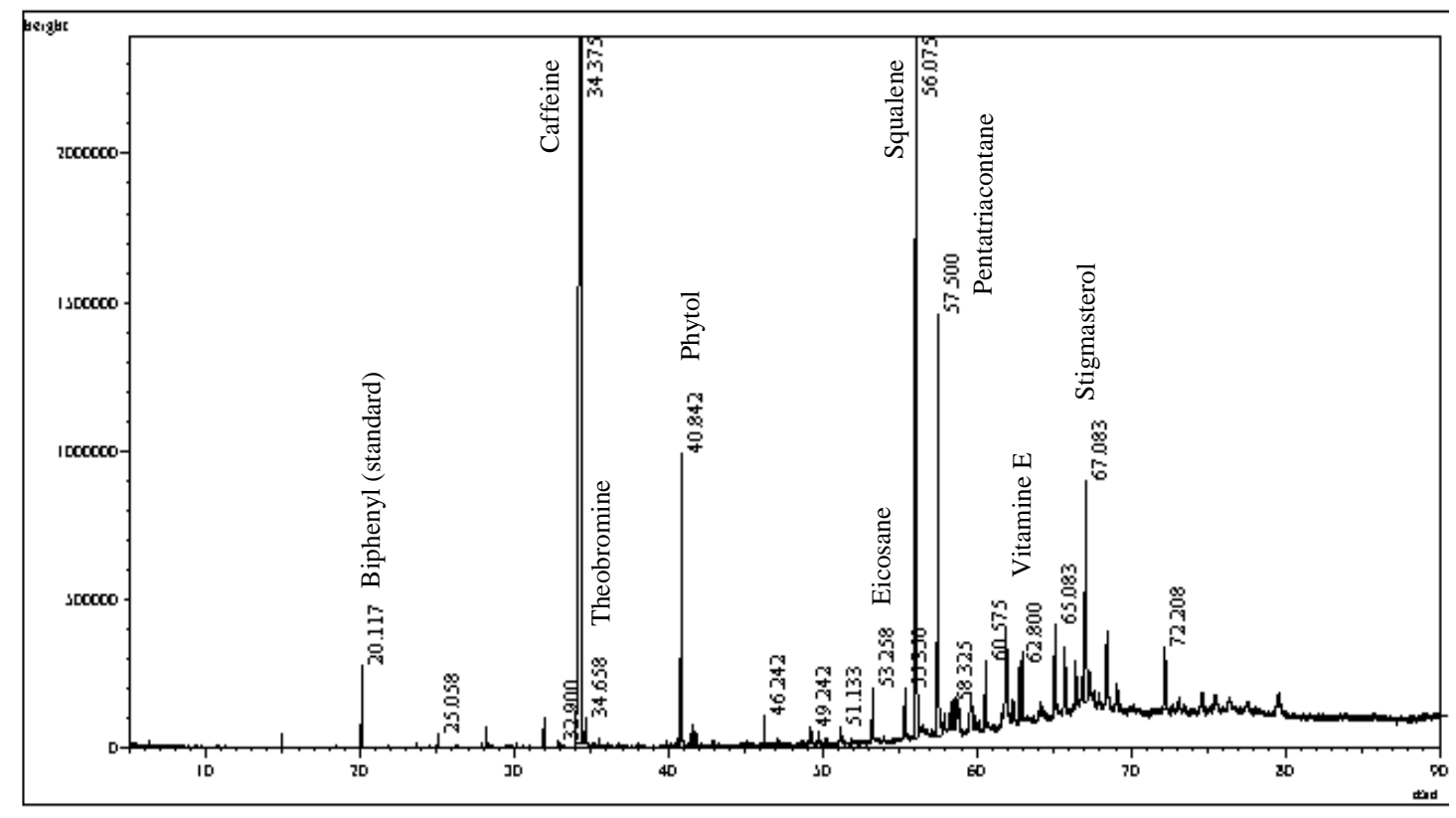

Figure 1 - Chromatographic profile of a supercritical carbon dioxide extract of Ilex paraguariensis (Chapecó population) 
Table 1 presents the content of the selected compounds in the extracts of each population of Ilex paraguariensis analyzed. Average values and experimental uncertainties (standard deviations) of each compound analyzed along with a statistical analysis of the results (Analysis of Variance coupled with the Tukey test at 95\% confidence level) are reported in this table. Significant differences between populations were observed for all the analyzed compounds. Caffeine concentration ranged between 334.93 $\mathrm{mg} / \mathrm{g}$ and $43.13 \mathrm{mg} / \mathrm{g}$ for Coronel Barros and Uribici populations, respectively. These values were within the interval observed by other authors using different extraction procedures (Reginatto et al., 1999; Saldaña et al., 1999, 2000, Esmelindro et. al., 2004). The low caffeine concentration observed in some populations (Caçador and Ubirici) indicated that it was possible to select populations with low caffeine, which was particularly important considering that estimates of caffeine intake due to maté tea consumption in Brazil, Uruguay and Argentina, exceeded by far intakes recorded for other beverages containing this alkaloid (Mazzafera, 1997).

Table 1 - Quantitative chemical distribution of selected organic compounds ( $\mathrm{mg} / \mathrm{g}$ of extract) in twenty Brazilian populations of Ilex paraguariensis".

\begin{tabular}{|c|c|c|c|c|c|c|c|c|}
\hline Population & Caffeine & Theobromine & Phytol & Squalene & Vitamin E & Eicosane & Stigmasterol & Pentatriacontane \\
\hline Áurea & $279.88 \pm 10.59^{a b}$ & $0.24 \pm 0.03^{b c}$ & $2.54 \pm 0.33^{\mathrm{def}}$ & $36.32 \pm 2.83^{c}$ & $12.35 \pm 1.07^{\mathrm{bc}}$ & $9.57 \pm 0.11^{\mathrm{a}}$ & $22.79 \pm 1.98^{\mathrm{cde}}$ & $11.90 \pm 1.79^{\mathrm{a}}$ \\
\hline B. Cotegipe & $172.62 \pm 3.29^{\mathrm{cd}}$ & $0.07 \pm 0.03^{\mathrm{f}}$ & $1.70 \pm 0.40^{\mathrm{fgh}}$ & $28.29 \pm 0.86^{\mathrm{cd}}$ & $8.92 \pm 1.49^{c}$ & $2.06 \pm 0.42^{\text {def }}$ & $19.91 \pm 1.55^{\mathrm{de}}$ & $3.64 \pm 0.39^{b c d}$ \\
\hline Cel Barros & $334.93 \pm 4.92^{\mathrm{a}}$ & $0.13 \pm 0.07^{\mathrm{de}}$ & $3.44 \pm 0.64^{\mathrm{de}}$ & $15.13 \pm 1.37^{\mathrm{efg}}$ & $3.05 \pm 1.75^{\mathrm{fg}}$ & $1.59 \pm 0.53^{\mathrm{efg}}$ & $36.33 \pm 0.49^{\mathrm{ab}}$ & $3.67 \pm 0.26^{\mathrm{bcd}}$ \\
\hline Erechim & $104.61 \pm 2.72^{d}$ & $0.47 \pm 0.18^{a}$ & $2.87 \pm 0.50^{\mathrm{de}}$ & $25.13 \pm 1.47^{\mathrm{cd}}$ & $6.41 \pm 0.78^{\mathrm{d}}$ & $5.17 \pm 0.39^{b}$ & $34.82 \pm 2.60^{\mathrm{ab}}$ & $5.47 \pm 0.89^{b}$ \\
\hline F. da Cunha & $131.76 \pm 3.95^{\mathrm{d}}$ & $0.11 \pm 0.01^{\mathrm{e}}$ & $25.50 \pm 0.81^{\mathrm{a}}$ & $21.29 \pm 0.54^{\text {cde }}$ & $7.81 \pm 0.14^{\mathrm{c}}$ & $1.70 \pm 0.30^{\text {defg }}$ & $39.07 \pm 2.61^{\mathrm{a}}$ & $6.04 \pm 0.82^{b}$ \\
\hline Ilópolis & $213.10 \pm 2.59^{b c}$ & $0.16 \pm 0.01^{\mathrm{d}}$ & $5.64 \pm 0.62^{\mathrm{cd}}$ & $53.18 \pm 2.12^{b}$ & $7.35 \pm 1.41^{\mathrm{cd}}$ & $1.40 \pm 0.25^{\mathrm{efg}}$ & $34.66 \pm 1.59^{\mathrm{ab}}$ & $3.92 \pm 0.25^{\mathrm{bcd}}$ \\
\hline Machadinho & $119.27 \pm 6.45^{\mathrm{d}}$ & $0.04 \pm 0.02^{f}$ & $0.31 \pm 0.54^{i}$ & $26.34 \pm 1.87^{\mathrm{cd}}$ & $4.44 \pm 0.15^{\mathrm{e}}$ & $0.43 \pm 0.21^{\mathrm{h}}$ & $14.49 \pm 0.67^{\mathrm{e}}$ & $4.71 \pm 0.64^{\mathrm{bcd}}$ \\
\hline São F. Paula & $180.47 \pm 1.11^{c}$ & $0.10 \pm 0.04^{\text {ef }}$ & $4.51 \pm 0.51^{\mathrm{cd}}$ & $13.14 \pm 0.85^{\text {efg }}$ & $6.23 \pm 1.35^{\mathrm{d}}$ & $2.05 \pm 0.25^{\mathrm{def}}$ & $30.27 \pm 0.55^{\mathrm{bc}}$ & $7.24 \pm 1.92^{b}$ \\
\hline V. Aires & $194.09 \pm 2.76^{c}$ & $0.12 \pm 0.04^{\mathrm{e}}$ & $2.27 \pm 0.07^{\mathrm{efg}}$ & $20.16 \pm 1.07^{\mathrm{de}}$ & $3.97 \pm 0.28^{\text {ef }}$ & $1.06 \pm 0.54^{\mathrm{g}}$ & $24.97 \pm 1.96^{\mathrm{cd}}$ & $4.76 \pm 0.26^{\mathrm{bcd}}$ \\
\hline V. Graeff & $127.88 \pm 1.29^{\mathrm{d}}$ & $0.39 \pm 0.14^{\mathrm{a}}$ & $2.06 \pm 0.79^{\text {efg }}$ & $4.08 \pm 0.16^{h}$ & $4.00 \pm 0.39^{\text {ef }}$ & $1.17 \pm 0.19^{\mathrm{fg}}$ & $25.87 \pm 0.54^{\mathrm{cd}}$ & $4.10 \pm 0.35^{\mathrm{bcd}}$ \\
\hline B. do Sul & $123.05 \pm 3.49^{\mathrm{d}}$ & $0.07 \pm 0.02^{\mathrm{f}}$ & $4^{\mathrm{h}}$ & $9 \pm 1.95^{\mathrm{fg}}$ & $75^{\mathrm{fg}}$ & & $18.44 \pm 1$ & $.73^{\mathrm{bcd}}$ \\
\hline Caçador & $58.64 \pm 1.29 \mathrm{df}$ & $0.20 \pm 0.04^{\mathrm{cd}}$ & $1.46 \pm 0.15^{\mathrm{gh}}$ & $3.98 \pm 0.93^{h}$ & $3.24 \pm 0.48^{\mathrm{f}}$ & $2.22 \pm 0.36^{\text {cde }}$ & $32.30 \pm 1.97^{\mathrm{bc}}$ & $5.16 \pm 0.43^{\mathrm{bcd}}$ \\
\hline Catanduvas & $165.72 \pm 1.48^{\mathrm{cd}}$ & $0.19 \pm 0.17^{\mathrm{bc}}$ & $6.18 \pm 0.35^{c}$ & $21.97 \pm 1.96^{\text {cde }}$ & $5.01 \pm 1.13 \mathrm{de}$ & $2.46 \pm 0.87^{\mathrm{cd}}$ & $24.28 \pm 1.14^{\mathrm{cd}}$ & $5.78 \pm 0.84^{b}$ \\
\hline Chapecó & $316.49 \pm 2.78^{\mathrm{a}}$ & $0.32 \pm 0.13^{b}$ & $15.64 \pm 3.13^{b}$ & $18.13 \pm 1.30^{\text {ef }}$ & $4.17 \pm 0.62$ ef & $2.12 \pm 0.19^{\mathrm{de}}$ & $43.00 \pm 1.83^{\mathrm{a}}$ & $5.05 \pm 0.60^{\mathrm{bcd}}$ \\
\hline Urubici & $43.13 \pm 1.79^{\mathrm{f}}$ & $0.29 \pm 0.05^{b c}$ & $1.07 \pm 0.14^{\mathrm{gh}}$ & $7.67 \pm 1.14^{\mathrm{g}}$ & $1.67 \pm 0.35^{\mathrm{g}}$ & $1.12 \pm 0.07^{\mathrm{fg}}$ & $15.35 \pm 1.24^{\mathrm{e}}$ & $2.94 \pm 0.26^{\mathrm{d}}$ \\
\hline Cascavel & $225.97 \pm 4.83^{b}$ & $0.11 \pm 0.08^{\mathrm{e}}$ & $2.06 \pm 0.61^{\mathrm{efg}}$ & $21.91 \pm 1.87^{\mathrm{cde}}$ & $4.71 \pm 0.17$ de & $2.91 \pm 0.12^{\mathrm{cd}}$ & $31.03 \pm 1.10^{\mathrm{bc}}$ & $5.91 \pm 0.80^{b}$ \\
\hline F. Beltrão & $172.24 \pm 7.79^{c}$ & $0.20 \pm 0.05^{\mathrm{cd}}$ & $2.59 \pm 0.17^{\mathrm{def}}$ & $95.06 \pm 2.19^{\mathrm{a}}$ & $47.02 \pm 1.94^{\mathrm{a}}$ & $3.23 \pm 0.49^{\mathrm{c}}$ & $30.59 \pm 1.78^{\mathrm{bc}}$ & $5.08 \pm 0.25^{\mathrm{bcd}}$ \\
\hline Irati & $237.60 \pm 4.54^{b}$ & $0.22 \pm 0.08^{\mathrm{cd}}$ & $1.93 \pm 0.20^{\mathrm{fgh}}$ & $19.98 \pm 0.98^{\text {def }}$ & $6.53 \pm 0.89^{\mathrm{d}}$ & $1.25 \pm 0.31^{\mathrm{efg}}$ & $22.27 \pm 0.57^{\text {cde }}$ & $3.58 \pm 0.17^{\mathrm{cd}}$ \\
\hline São M. Sul & $134.88 \pm 2.16^{\mathrm{d}}$ & $0.17 \pm 0.01^{\mathrm{d}}$ & $1.24 \pm 0.11^{\mathrm{gh}}$ & $96.66 \pm 2.65^{\mathrm{a}}$ & $16.44 \pm 1.78^{b}$ & $1.86 \pm 0.36^{\mathrm{defg}}$ & $17.95 \pm 1.35^{\mathrm{de}}$ & $4.09 \pm 0.19^{\mathrm{bcd}}$ \\
\hline Ponta Porã & $221.24 \pm 1.83^{b}$ & $0.11 \pm 0.02^{\mathrm{e}}$ & $6.09 \pm 2.07^{c}$ & $24.21 \pm 1.52^{\mathrm{cd}}$ & $7.97 \pm 0.45^{\mathrm{c}}$ & $2.59 \pm .0 .59^{\mathrm{cd}}$ & $36.57 \pm 1.01^{\mathrm{a}}$ & $5.79 \pm 0.32^{b}$ \\
\hline
\end{tabular}

"Data represent average values of 18 analysis (three samples with two extraction runs and 3 injection replications). Mean values followed by the same letter were not significantly different (Duncan at $5 \%$ ).

With the exception of the populations collected at Aurea and Coronel Barros, those from the states of Rio Grande do Sul and Santa Catarina, below parallel $26^{\circ} \mathrm{S}$, exhibited lower caffeine content than the populations from Paraná and Mato Grosso States. This difference may be associated with climatic and physiological characteristics like photoperiod, seasonal temperature variations, light intensity, and leaves age, factors that influence the accumulation of methylxanthines, particularly caffeine (Ashihara, 1993; Mazzafera, 1994; Hoft et al., 1996). Similar results were found by 
Athayde and Schenkel (2000) regarding the profile of methylxanthines in four Brazilian native populations of I. paraguariensis.

Theobromine was detected in low concentration in all the populations studied, and theophylline was not detected. Theobromine concentrations were within the range previously reported for maté leaves (Reginatto et al., 1999; Saldaña et al., 1999, 2000). The absence of theophylline be associated with the low solubility of this specific methylxanthine in $\mathrm{CO}_{2}$ (Saldaña et al., 2000).

Phytol, a diterpenic acyclic alcohol used to synthesize vitamin $\mathrm{E}, \mathrm{K}$ and widely employed in several fragrance products, presented low concentrations in most of the populations analyzed, with the exception of Flores da Cunha $(25.50 \mathrm{mg} / \mathrm{g})$ and Chapecó (15.64 mg/g). As phytol is one of the chlorophyll precursors (Ischebeck et al., 2006), variation in its content may be due mainly to the rate of sun exposure and age of leaves.

Squalene (triterpene) is an intermediate in the biosynthesis of sterols (Pogliani et al., 1999) and has demonstrated proliferate activity in animal cancer studies, some radio protective effects, and may also have a cholesterol-lowering effect, but this has not been tested in humans (Gregory and Kelly, 1999). As can be seem in Table 1, great differences were found for the content of this compound, with major concentrations verified in São Mateus do Sul $(96.66 \mathrm{mg} / \mathrm{g})$ and Francisco Beltrão $(95.06 \mathrm{mg} / \mathrm{g})$ whereas the lowest values were found in Victor Graeff $(4.08 \mathrm{mg} / \mathrm{g})$ and Caçador $(3.98 \mathrm{mg} / \mathrm{g})$.

It is well known that in all photosynthetic organisms, vitamin E (tocopherols) and other isoprenoids have important photoprotective role, either by dissipating excess excitation energy as heat or by scavenging reactive oxygen species (ROS) and suppressing lipid peroxidation. Compelling evidence indicates that these nonubiquitous isoprenoids might be particularly relevant in adapting plants to adverse climatic conditions by serving as additional and/or alternative protection mechanisms (Peñuelas and Munné-Bosch, 2005). Apart from Francisco Beltrão $(47.02 \mathrm{mg} / \mathrm{g})$ population, the concentration of vitamin $\mathrm{E}$ did not present great variations within populations analyzed.

Positive correlations (Pearson correlation) were observed between phytol and vitamin E concentrations (0.634) and stigmasterol and squalene, its biosynthetic precursor (0.807).
Stigmasterol is a commonly found sterol in vegetables and presented variations in the range of 43 to $14.49 \mathrm{mg} / \mathrm{g}$ in the populations investigated.

Eicosane and pentatiacontane are alcanes present in the waxes of leaves; the greatest concentration was found in the population of Áurea, thus indicating differences in the age of leaves and some hydric stress in the collect period.

A cluster analysis (UPGMA algorithm), based on the Euclidian distances calculated from the quantitative analysis of the extracts, disclosed, with few exceptions, the three samples that represent each population grouped together, indicating that, in general, the populations were characterized by a particular chemical composition. Some populations exhibited a higher chemical variation (Catanduvas, Cascavel, Barão de Cotegipe, and Ilópolis), and could be considered as appropriate materials for breeding programs.

Chemical variation was not related with macroclimatic parameters and geographical origin indicating that the chemical variations observed be the result of the genetic constitution of each population and/or microclimatic and edaphological characteristics of the site of collection. Genetic and local environmental influence on the chemical characteristics of plants have been largely documented. Based on the early observations that plants of different chemical composition were commonly found at the same site, growing under similar conditions, qualitative chemical composition was considered to be under genetic control rather than environmental control (Murtagh and Smith, 1996). Conversely, quantitative variations may fluctuate in response to environmental conditions (Murtagh and Etherington, 1990). Esmelindro et al. (2004) found a remarkable variation in the caffeine content in maté extract from leaves of distinct ages and trees cultivated under different conditions of light intensity. This phenotypic plasticity was the result of genotype by environment interactions and occurs both within and among populations (Ackerly et al., 2000).

\section{ACKNOWLEDGEMENTS}

The authors would like to express their gratitude to CNPq, FAPERGS and SCT - RS for the financial support of this research. 


\section{RESUMO}

A extração empregando dióxido de carbono a altas pressões em erva-mate (Ilex paraguariensis St. Hil.), tem sido justificada pelo crescente interesse desta matriz vegetal ou de parte de seus constituintes na formulação de novos produtos, tais como cosméticos e medicamentos, entre outros. Neste contexto, o objetivo do presente trabalho é avaliar a distribuição química de compostos semi-voláteis em 20 populações de erva-mate coletadas em toda área de distribuição desta espécie no Brasil. 30 plantas foram selecionadas para produzir a amostra de cada população. Os extratos de cada amostra foram obtidos por extração com dióxido de carbono a alta pressão e, posteriormente, foram analisados por CG/EM. A quantificação de alguns compostos semi-voláteis presentes nos extratos (cafeína, teobromina, fitol, esqualeno, vitamina E, eicosano, pentatriacontano e stigmasterol), apresentaram variações significativas entre as concentrações dos diferentes compostos analisados nas diferentes populações, os quais não estão relacionados com origem geográfica ou com características de macroclima. Os resultados apontam para a importância dos fatores genéticos e/ou fatores de microclima sobre a composição química desta espécie.

\section{REFERENCES}

Ackerly, D.D., Dudley, S.A., Sultan, S.E., Schmitt, J., Coleman, J.S., Linder, C.R., Sandquist, D.R., Geber, M.A., Evans, A.S., Dawson, T.E., Lechowicz, M.J. (2000), The evolution of plant ecophysiological traits: recent advances and future directions. BioScience, 50, 979-995.

Ashihara, H. (1993), Purine metabolism and the biosynthesis of caffeine in maté leaves. Phytochemistry 6, 1427-1430.

Athayde, M.L., Schenkel, E.P., (2000), Metilxantinas e saponinas em quatro populações de Ilex paraguariensis St. Hil. In: Anais Do $2^{\circ}$ Congresso Sul-Americano Da Erva-Mate, 2000, Encantado, RS, Brazil, 121-124.

Clifford, M., Ramirez-Martinez, J.R. (1990), Chlorogenic acid and purine alkaloids contents of maté (Ilex paraguaryensis) leaf and beverage. Food Chem. 35, 13-21.
Coelho, G. C., Mariath, J. E. A., Schenkel, E. P. (2002), Populational Diversity on Leaf Morphology of Maté (Ilex paraguariensis A. St.-Hil., Aquifoliaceae). Braz. Arch. Biol. Technol. 45 (1), 47-51.

Esmelindro, A. A.; Santos, J.G.; Mossi, A.; Jacques, R.A.; Dariva, C. (2004), Influence of Agronomic Variables on the Composition of Maté Tea Leaves (Ilex paraguariensis) Extracts Obtained from $\mathrm{CO} 2$ Extraction at $30 \mathrm{C}$ and 175 bar. J. Agric. Food Chem., 52, 1990-1995.

Esmelindro, M.C., Toniazzo, G., Dariva, C., Oliveira, D., Lopes, D. (2005), Effects of processing conditions on the chemical distribution of maté tea leaves extracts obtained from $\mathrm{CO}_{2}$ extraction at high pressures. J. Food Engineering, 70 (4), 588-592.

Gregory, S., Kelly, N.D. (1999), Squalene and its potential clinical uses. Alternative Medicine Review, 4(1), 29-36.

Hoft, M., Verpoorte, R., Beck, E. (1996), Growth and alkaloid contents in leaves of Tabernaemontana pachysiphon Stapf. (Apocynaceae) as influenced by light intensity, water and nutrient supply. Oecologia, 107, 160-169.

Ischebeck, T., Zbierzak, A.M., Kanwischer, M., Dormann, P. (2006), A salvage athway for phytol metabolism in Arabidopsis. J. Biol. Chem. 281(5), 2470-2477.

Kawakami, M., Kobayashi, A. (1991), Volatile constituents of green maté and roasted mate. J. Agric. Food Chem., 39, 1275-1279.

Mazzafera, P. (1994), Caffeine, Theobromine and theophylline distribution in Ilex paraguariensis. $R$. Bras. Fisiol. Veg., 6, 149-151.

Mazzafera, P. (1997), Matédrinking: caffeine and phenolic acid intake. Food Chem., 60, 67-71.

Murtagh, G.L., Etheringtion, R.J. (1990), Variation in oil concentration and economic return form tea-tree (Melaleuca alternifolia Cheel) oil. Aust. J. Agric. Res., 30, 675-679.

Murtagh, G.L., Smith, G.R. (1996), Month of harvest and yield components of tea tree. II- oil composition, concentration and yield. Aust. J. Agric. Res., 47, 817827.

Oliveira, Y.M.M., Rotta, E. (1985), Área de distribuição natural de erva-mate (Ilex paraguariensis St. Hil.). Seminário sobre atualidades e perspectivas florestais, 10. Curitiba, EMBRAPA-CNPF documentos, 15, 17-36.

Peñuelas, J., Munné-Bosch, S. (2005), Isoprenoids: an evolutionary pool for photoprotection, Trends in Plant Science, 10(4), 166-169.

Pogliani, L., Milanesio, M., Ceruti, M., Viterbo, D. (1999), Conformational and dynamical study of squalene derivatives. III: azasqualenes and solvated squalene. Chemistry and Physics of Lipids, 103(1-2), 81-93. 
Reginatto, F.H., Athayde, M.L., Gosmann, G., Schenkel, E.P. (1999), Methylxanthines accumulation in Ilex species - caffeine and theobromine in Ervamate (Ilex paraguariensis) and other Ilex species. $J$. Braz. Chem. Soc., 6, 443-446.

Rodrigues, M.R.A., Caramão, E.B., Santos, J.G., Dariva, C., Oliveira, J.V. (2003), The effects of temperature and pressure on the characteristics of the extracts from high-pressure $\mathrm{CO}_{2}$ extraction of Majorana hortensis Moench. J. Agric. Food Chem., 51, 453-546.

Rodrigues, M.R.A., Krause, L.C., Caramão, E.B., Santos, J.G., Dariva, C., Oliveira, J.V. (2004), Chemical composition and extraction yield of the extract of Origanum vulgare obtained from sub- and supercritical $\mathrm{CO}_{2}$. J. Agric. Food Chem., 52, 30423047.

Saldaña, M.D.A., Mazzafera, P., Mohamed, R.S. (1999), Extraction of purine alkaloids from maté (Ilex paraguariensis) using supercritical $\mathrm{CO}_{2}$. J. Agric. Food Chem., 47, 3804-3808.
Saldaña, M.D.A., Zetzl, C., Mohamed, R., Brunner, G. (2002), Extraction of Methylxantines from Guaraná Seeds, Maté Leaves and Cocoa Beans Using Supercritical Carbon Dioxide and Ethanol, J. Agric. Food Chem., 50, 4820-4826.

Sousa, E. M. B. D. de, Câmara, A. P. C., Costa, W. A. Costa, A. C. J., Oliveira, H. N. M., Galvão, E. L., Marques, M. M. O. (2005), Evaluation of the extraction process of the essential oil from Cymbopogon schoenanthus with pressurized carbon dioxide. Braz. Arch. Biol. Technol. 48, 231-236.

Winge, H.,Wollheim, C.; Cavalli-Molina, S.; Assmann, E.M.; Bassani, K.L.L.; Amaral,M.B.; Coelho, G.C.; Freitas-Sacchet, A.M.O.; Butzke, A.; Valduga, A.T.; Mariath, J.E.A. (1995), Variabilidade genética em populações nativas de erva-mate e a implantação de bancos de germoplasma. In: Erva-mate: Biologia $e$ Cutura no Cone Sul. Porto Alegre: Ed. da Universidade/UFRGS, p.323-345. 